\title{
Structural appraisal of climate-induced effects on E. Torroja's unreinforced brickwork shell structure of the IETcc winter garden
}

\section{Evaluación estructural de los efectos climáticos en la cubierta de mampostería no reforzada del invernadero del IETcc proyectada por E. Torroja}

$\underline{\text { O. RíO }}^{(*)}$, D. Theodossopoulos ${ }^{(*)}$

\section{ABSTRACT}

In this paper, the design and causes of deterioration of the Winter Garden located in the Eduardo Torroja Institute for Construction Sciences (IETcc) in Madrid, as well as the structural rehabilitation works carried out are discussed. The structural and architectural scheme was devised by E. Torroja and is examined using numerical analysis under dead load. This allows the failure pattern of the arches and shells to be assessed, as a consequence of water ingress through the cracks formed and settlement, as also the effectiveness of the repair techniques applied in 2009.

Keywords: Crack repairs; masonry shell; unreinforced brickwork; Torroja; FE analysis.

\section{RESUMEN}

En este trabajo, se discuten el diseño y las causas de deterioro del edificio del invierno situado en el Instituto de Ciencias de la Construcción Eduardo Torroja (IETcc) en Madrid, así como las obras de rehabilitación de mantenimiento de la estructura ejecutadas. El esquema estructural y arquitectónico ideado por E. Torroja se examinó utilizando análisis numérico considerando el efecto de la carga muerta. Esto permite analizar el tipo de fallo observado en los arcos y la cubierta abovedada, como consecuencia del asentamiento y de la entrada de agua a través de las fisuras formadas así como la eficacia de las técnicas de reparación realizadas en 2009.

Palabras clave: Reparación de fisuras; bóvedas de mampostería; mampostería de ladrillo no reforzada; Torroja; análisis EF.

(*) Instituto de Ciencias de la Construcción Eduardo Torroja (IETcc-CSIC). Madrid (España).

${ }^{(* *)}$ Architecture, Edinburgh College of Art, University of Edinburgh. Edinburgh (United Kingdom)

Persona de contacto/Corresponding author: rio@ietcc.csic.es (O. Río)

Cómo citar este artículo/Citation: Río, O., Theodossopoulos, D. (2014). Structural appraisal of climate-induced effects on E. Torroja's unreinforced brickwork shell structure of the IETcc winter garden. Informes de la Construcción, 66(536): e042, doi: http://dx.doi.org/10.3989/ic.14.124.

Licencia / License: Salvo indicación contraria, todos los contenidos de la edición electrónica de Informes de la Construcción se distribuyen bajo una licencia de uso y distribución Creative Commons Reconocimiento no Comercial 3.o. España (cc-by-nc). 


\section{INTRODUCTION}

The main areas of concern of structural damages are usually design deficiencies, problems during construction, material durability or compatibility and foundations (1) (2). Nevertheless, structural damages and failures are frequently attributed to a series of factors rather than just a single cause as it is the example discussed in this paper.

The Winter Garden (Invernadero) designed by Eduardo Torroja, is one of the singular buildings which dates from the first years of the actual Eduardo Torroja Institute for Construction Sciences (IETcc) research complex, the majority of which were built in the early 1950's (3) (4). It is a very interesting structure formed exclusively in brickwork with arches as the main vertical load-bearing elements and is inserted within the natural slope of the ground.

Until a few years ago however, the building was in a state of total neglect and presented some serious structural damages and an overall degradation of the fabric. The principal crack pattern and deterioration of arch elements and roof shell was mainly due to the ground movement of the slope, the ingress of rain water and the lack of a maintenance programme. A rehabilitation project was set up in 2008 aiming to transform the building into a space for meetings and workshops (5), as the use as a Winter Garden was already obsolete.

The initial aim of this study is to assess the strength of the structural systems and forms used and understand the causes of the crack pattern. Ultimately, this research phase of the project can re-evaluate the conservation options with regards to the deteriorated structural state of the building and the durability of the materials, as also explore the effect of the soil conditions on the stability of the building. Furthermore, the strength of specific areas of the building following strengthening and repairs of main cracks in a way compatible and respectful to the original design are discussed. The arches and flat vaults will be analysed with numerical models that will assess the performance of the original scheme and allow in a later stage to assess the deterioration process and simulate the possible strengthening solutions.

Although the major factors of the deterioration were identified during the works and a monitoring of the crack pattern evolution during more than a year was carried out (6), further problems associated with subsidence as well as material durability can lead to complex long term deformations of the brick structural elements which need to be also explored.

\section{THE BUILDING}

\subsection{Background}

The Winter Garden of the actual Eduardo Torroja Institute for Construction Sciences (IETcc) was designed by Eduardo Torroja himself in the 1950's and is one of the singular structures built during the first years of the research complex (4). The building is located on a slope (Figure 1) in the surroundings of the sport area and is one of the few structural masonry works designed by Torroja (7) (8) (9).

Although various papers describe in depth the different spaces of the entire compound (3) (7) (9) (10) (11), only

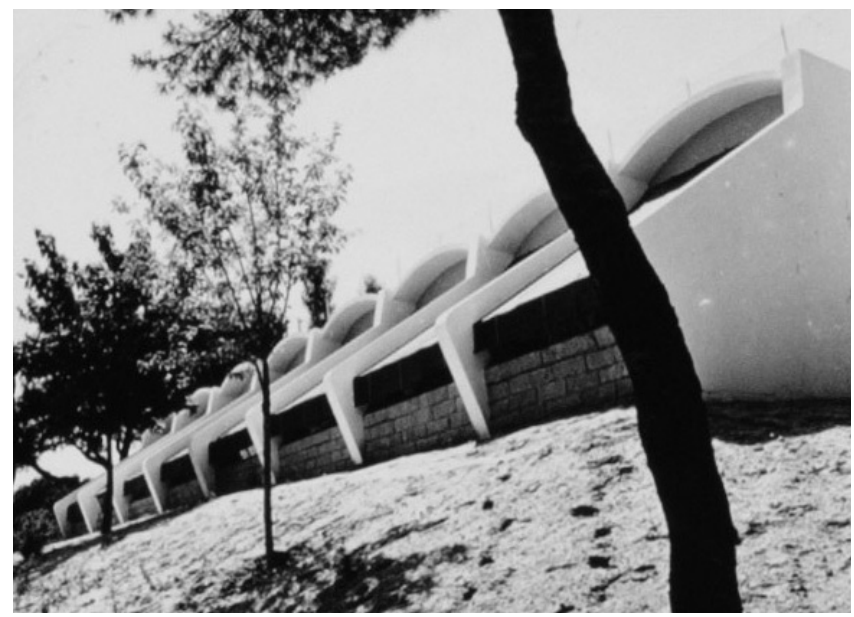

Figure 1. South elevation of the Winter Garden of the IETcc (4).

limited information exists related to this specific building (4) (12). Nevertheless, it is clear by considering the original plans reproduced in Figure 2 (4) and also by checking the photographic files available on the IETcc records (Figure 1 and 3), that its main function was to be used as a winter garden.

The current building (Figure 3b) replaces a previous one (Figure 3a) located on the site and it is the one that the Informes de la Construcción No. 58 mentions as part of the heating installation of the newly built IETcc (4). After construction, the building performed its functioned for some time.

Slowly however, reductions in maintenance personnel and the plantation of surrounding trees resulted in the space losing its identity (Figure 4). Eventually, the deterioration of the building and its immediate area meant it would be used for storage of gardening or sports equipment.

There have been however many attempts to refurbish this space and reports on its conservation state (6) could have led to a project. However, in 2008 as a result of an initiative from the Board of IETcc, Drs. Oteiza, Olaya and Fullea carried out a preliminary feasibility study (5) towards the use of the building as a multi-functional space (meetings, exhibitions etc). Their report made a succinct summary of the essential aspects for the restoration of the space and its transformation into a sustainable, energy efficient building, with a minimum environmental impact. This is based on a self-sufficiency premise where suitable materials and construction techniques are chosen accordingly but no changes are envisaged to the original scheme of the building, both in terms of fabric (materials, structure) and its solar-gain strategy to facilitate the growth of plants.

\subsection{Building location and description}

The Winter Garden building is situated close to the tennis court wall coping, over a sloped bed partially filled on the south-east (Figure 2 and Figure 5). It is formed by a main space of six modules of $5.08 \mathrm{~m} \times 7,05 \mathrm{~m}$ and two anterooms (Figure 2) of similar area. The whole area is covered by eight shallow barrel vaults leaning towards north and a glass structure leaning to the south. The main space forms an open-plan with planting beds along the longitudinal edge, 

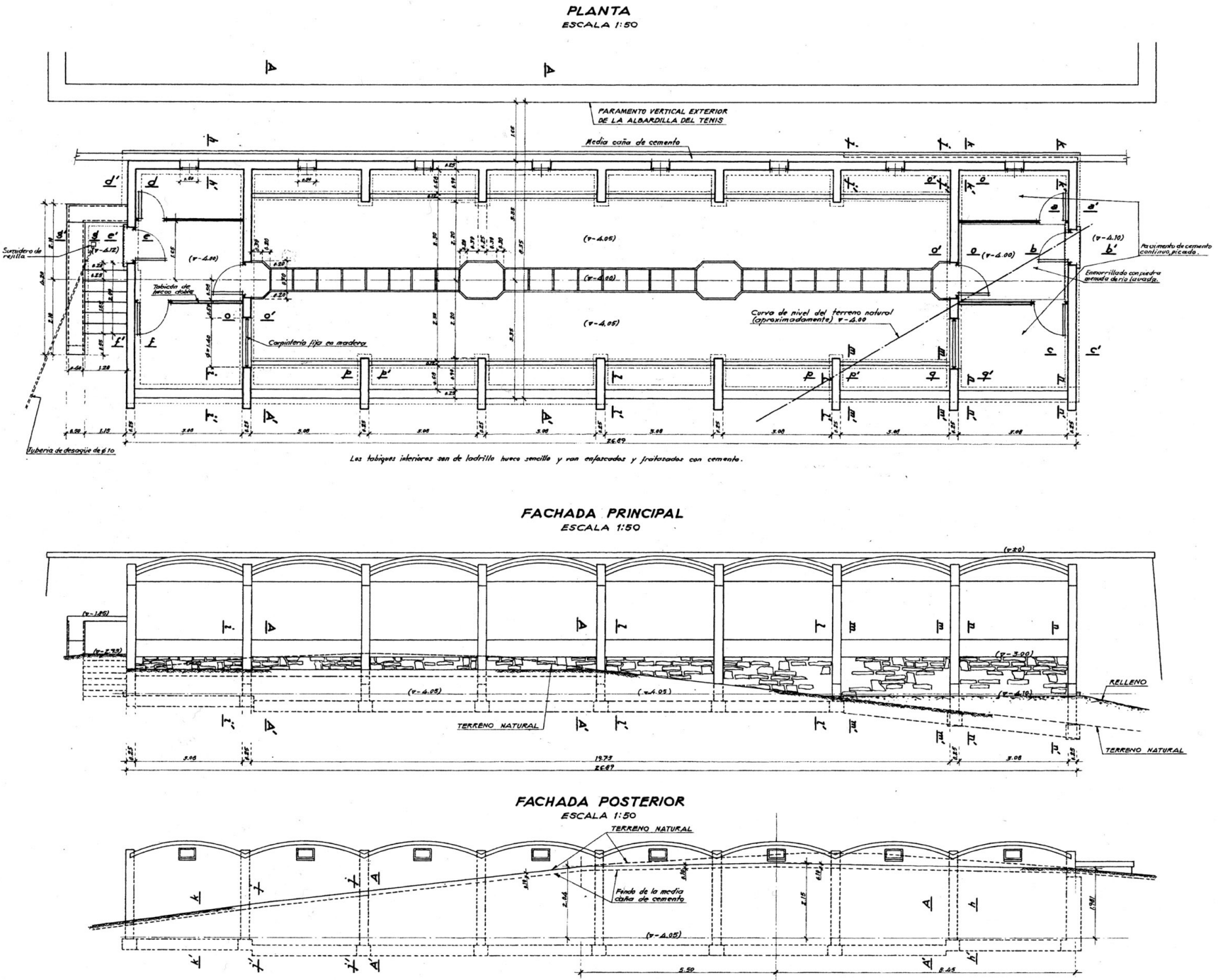

Figure 2. Winter Garden plan and elevations dated from 1955 (4).

only interrupted by the open arcades which act as support of the vaults (Figures $3 \mathrm{~b}$ or $4 \mathrm{a}$ ). The floor with the exception of the middle paved pavement was made of rammed earth (Figure 3b).

All the structural elements (vaults and arcades) as well as the walls were made of a single leaf of unreinforced brickwork, a quite exceptional application by Torroja (8) (13), and then rendered with a trowel applied cement screed. Each arch has a circular profile, of a $4.4 \mathrm{~m}$ span and $2.5 \mathrm{~m}$ rise (Figure 6), springing from deep returns on the walls. The thickness of the arch and return is $0.25 \mathrm{~m}$.

The arches support a series of shallow brickwork vaults with a clear span $\mathrm{L}=3.08 \mathrm{~m}$ and a rise $\mathrm{F}=0.4 \mathrm{~m}(\mathrm{~L} / \mathrm{F}=7.7)$, which slope $15^{\circ}$ towards the back (Figure 6). The vaults roof the colder North side of the building while the vital daylight enters from the glazed South face (Figures 1). Not much information has been provided on structural reinforcement of the masonry or the connections between the elements (Figures 2 and 5). They were also rendered with cement and no sheeting was applied to cover the roof, with the slope expected to discharge rainwater to gutters at the back side (Figure 4b). The arches are quite pronounced on the extrados of the vaults, functioning actually as ribs that contain the spandrels. No information is either available on the presence of fill on the spandrels.

\subsection{The condition of the building}

As part of those preliminary studies, in-situ surveys were carried out that indicated the same type of deterioration at both the masonry arches and shell materials consisting of cracked/crumbling mortar and masonry render damage. Subsequently, the extent and location of the damage was explored in order to determine the main causes, the adequate method for the assessment of the structural safety and last but not least the repair options.

As mentioned, the building went through a long period of neglect. The result was a deterioration of the roof's waterproofing (Figure $7 \mathrm{a}$ and $7 \mathrm{~b}$ ) and some corrosion of the metal frame of the glazing (Figure $7 \mathrm{c}$ ). There is a clear presence of dampness at the fabric, especially towards the back side, probably accelerated by lack of maintenance of the gutters. The pattern of these cracks and the effect of the moisture decreases along the axis of the building in the East-West direction, towards the area of the natural land fill. 

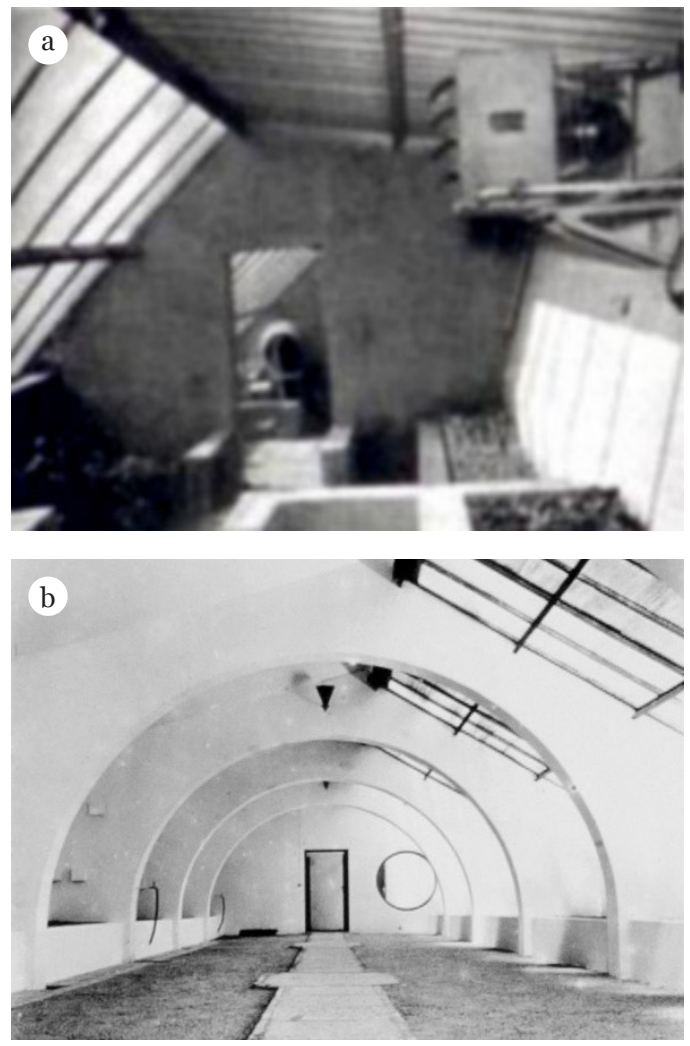

Figure 3. a) previous winter garden (12),

b) actual winter garden in 1955 (4)

Regarding the masonry arches, they present a main crack that runs primarily through the whole cross-section off the keystone towards the north wall and other smaller ones in the area in between. Although they appear in all the arches, their size and especially width is decreasing towards the west end (Figure 4a). Similarly, the extent of the damage due to moisture penetration decreases when moving from east to west.

So far as the roof barrel vaults are concerned, they present cracks along the east-west axis mainly on the north half of the vault (Figure $7 \mathrm{~b}$ ) as also perpendicular cracks located next to the arch elements (Figure 7a) and along the main axis of the vault. Similar to the arch damages, their size decrease towards the west end of the building. Moisture damage follows the crack pattern but does not decrease so much, and is greater on the middle vault, being more pronounced as cracks at the mortar joints.

The separation between the vault and north wall can be clearly observed along the different bays (open areas between arches), while the typical cracks, which usually appear on the
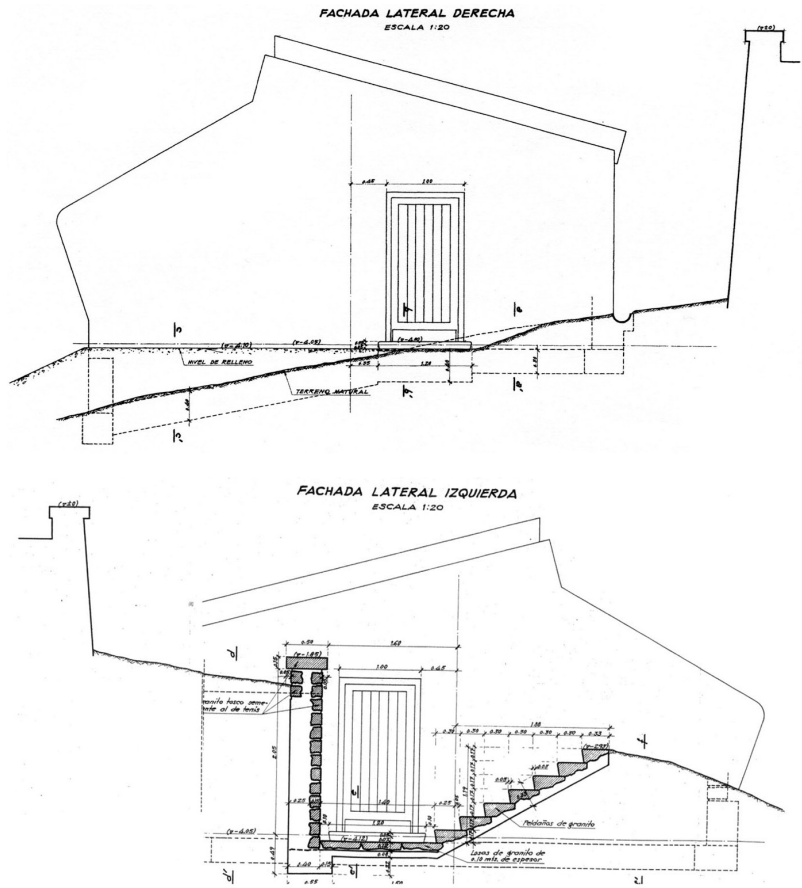

Figure 5. Level of earth between West and East façades of actual winter garden as it is shown in the original IETcc plans (4).

corner of windows at ground settlement, only appear on the bays located on the eastern part of the building (Figure $7 \mathrm{~b}$ ).

No significant damages were observed on the structural elements near the windows with the exception of those where the south wall joined the glazing (Figure 7c). A large number of glass panels were broken; the steel structure had deteriorated and water tightness sealant was nonexistent. The doors and window frames of the north wall also showed damage signs.

\section{STRUCTURAL APPRAISAL}

\subsection{The original scheme}

The small size of the building and the modest loads that were expected to act did not require a demanding structural scheme. Due to the orientation of the building, the temperature variations on the steel frame that holds the glazing could have caused significant expansion, which would need to be accommodated or isolated from the arches and vaults. The vaults shed their weight and thrust on the transverse arches/ ribs and they are also supported upon a wall at their back (North) end (Figure 4a). Most probably the structure was empirically sized by Torroja and he would rely upon experienced bricklayers who still had
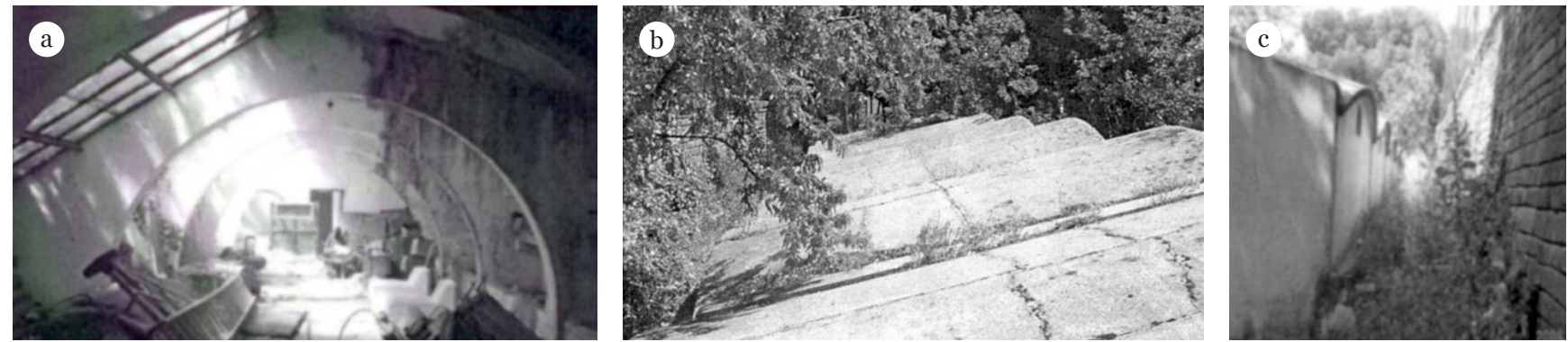

Figure 4. Aspect of the interior (a) and exterior (b) of Winter Garden and (c) surrounding area in 2008. 

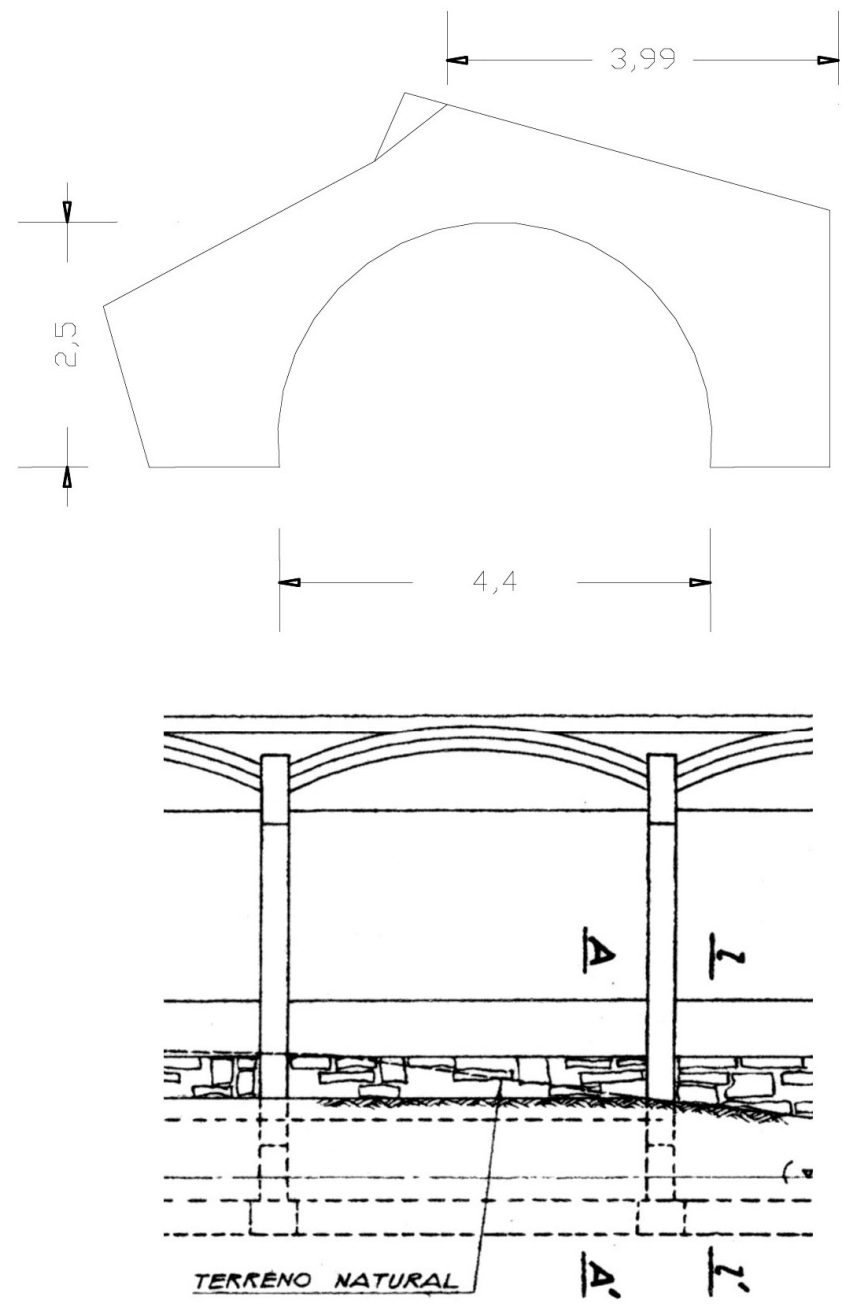

Figure 6. The geometry of the arches.

the knowledge of building arches and shallow vaults, as the techniques were widely used in Madrid until the 1960's (14).

\subsection{The damage of the fabric}

The degradation of the joints at the vaults led to water ingress to the arches and the weakened bond between the bricks caused cracks on the vaults and hinges at the crown of the arches towards the spandrels and the back side, partially buried in the natural slope. There are some pronounced cracks in the longitudinal axis of the shells (Figure $7 \mathrm{~b}$ ) and spread is prevented probably due to the mutual constraint of the adjacent bays along the arches (Figure 2) and the diaphragm action at the back. Transverse (hoop) cracks are also apparent, mainly along the bed joints of the brickwork (Figure 7b) but the extrados also shows a series of cracks, also closer the longitudinal apex (Figure $7 \mathrm{a}$ ).

It seems that once the hoop cracks had formed due to the deterioration of the joints, the vault was transformed into a series of increasingly independent arches. Being made of only one layer of brickwork and quite shallow, they exerted higher thrusts once the load-sharing had disappeared and eventually a hinge was formed at their crown, which eventually joined to form a longitudinal crack along the barrel.

As far as the deformation of the arches is concerned, the asymmetric crack pattern is due to the higher weight of the vault (at the $\mathrm{N}$ side in Figures $4 \mathrm{a}$ and $7 \mathrm{a}$ ) and the water ingress that has caused the decay of the mortar joints next to the spandrels. There may also be more complex interactions between the arches and the vaults and a more detailed analysis of the behaviour is carried in the next section in order to get more insight to the distribution of the loads.

\section{ASSESSMENT OF THE PERFORMANCE AND MODELLING}

A plain Finite Element model of the load-bearing structures was created to study the distribution of the loads. The Abaqus software was used and the structure was simulated with shell elements, assigning the thickness of the masonry (0.25 $\mathrm{m}$ ) as a parameter and following the geometry in Figures 2 and 6. Bay 3 is considered as representative of the structure and symmetric boundary conditions are applied on the sides to simulate the presence of the adjacent bays.

The actions considered are only the self-weight of the structure (assumed as $20 \mathrm{kN} / \mathrm{m}^{3}$ ). Typical values for the mechanical properties of non-reinforced brickwork were used (15) (16) (17) as no other data are available. The aim of the model is to understand the pattern of the deformation, rather than assess exact values of displacements or stress distribution. A more detailed and accurate model can be validated afterwards with in-situ measurements of the deformation or properties of the material (Table 1).

The analysis shows the high reserves in strength of the form under the ideal conditions considered here. The deformation of the model in Figure 8 shows a higher concentration of vertical displacement at the inner end of the vault, above the lintel of the window, but the values are overall small, to a maximum of $0.1 \mathrm{~mm}$. A study of the distribution of the stresses at the extrados of the vault (Figure 9) shows the middle strip of the vault cantilevers towards the window (axial tensile stresses S11 at both ends), while in the hoop
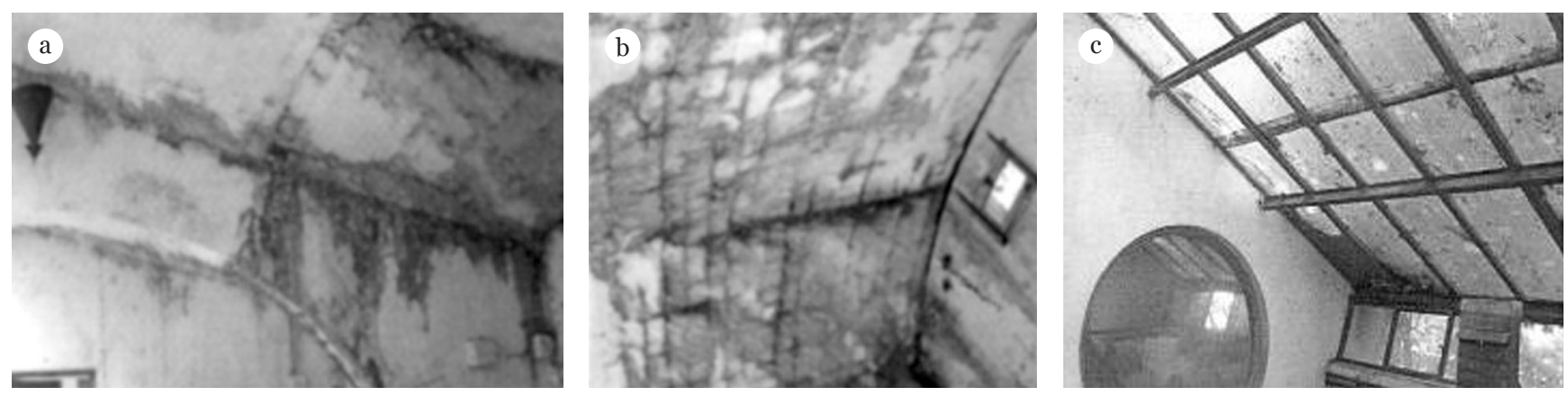

Figure 7. Examples of damages observed: a) on the first or easternmost arch, b) on the bay 3 vault and (c) their $\mathrm{N}$ wall. 
Table 1. Mechanical properties considered for the unreinforced brickwork in N/mm²

\begin{tabular}{|l|c|c|}
\hline & Axial direction (1) & Hoop direction (2) \\
\hline Modulus of elasticity E & 10642 & 15509 \\
\hline Compressive strength & -7 & -18 \\
\hline Tensile strength & 0.7 & 1.8 \\
\hline
\end{tabular}

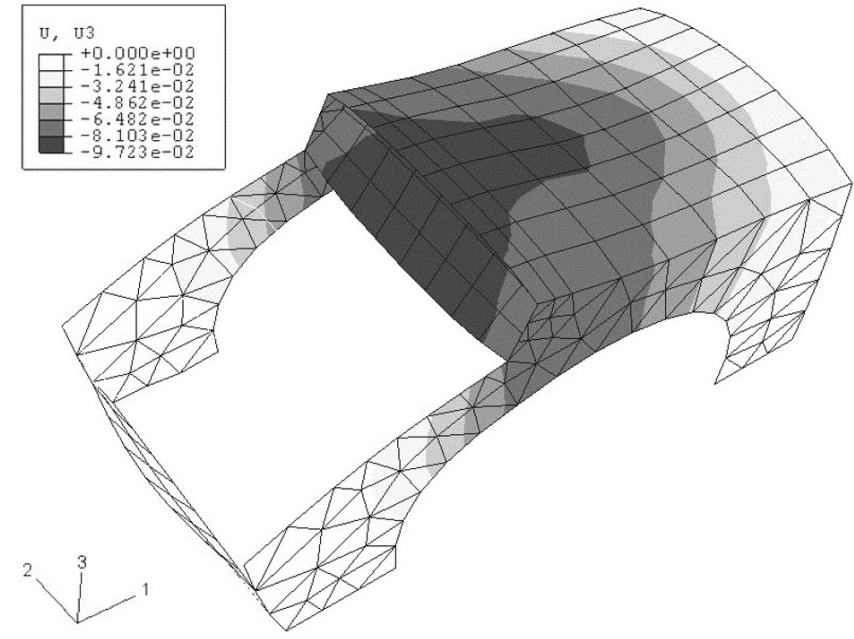

Figure 8. Deformation and deflections of the FE model for bay 3 (in $\mathrm{mm}$ ).
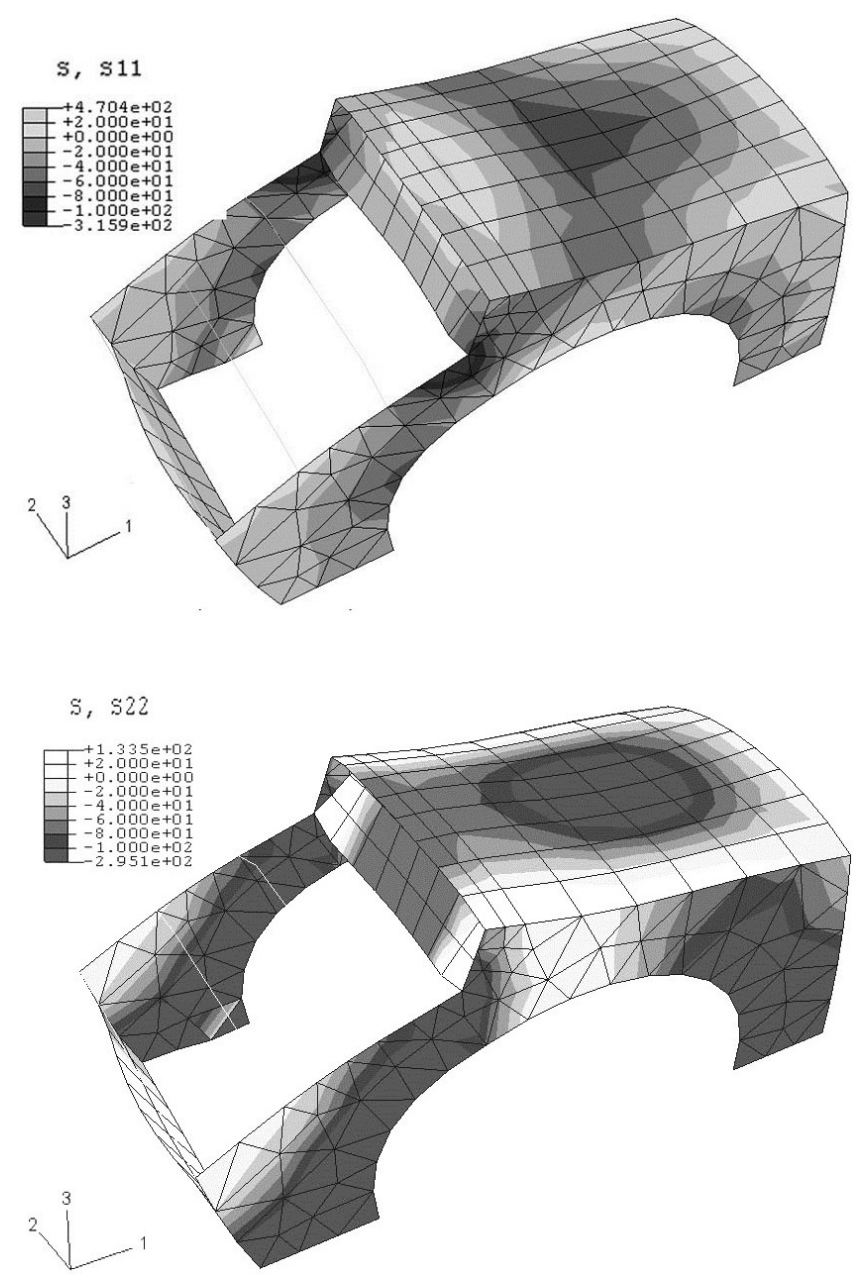

Figure 9. Loads at the extrados of the vaults in bay 3 in the axial (S11) and hoop direction (S22) in $\mathrm{kN} / \mathrm{m}^{2}$. Stresses S11 have a radial direction in the case of the arches. direction (S22) the tensile forces appear along the edge with the arches. The latter tensile forces are higher along those edges and this is where the cracks are expected to start if a high load is considered to act. The overall values however are small (maximum $130 \mathrm{kN} / \mathrm{m}^{2}$ or $0.13 \mathrm{~N} / \mathrm{mm}^{2}$ in the hoop direction), while max compressive stresses are about $0.3 \mathrm{~N} /$ $\mathrm{mm}^{2}$, i.e. well below the assumed strength.

The deformation of the vault spreads further into the arch and the area of the crown deforms relatively higher. The distribution of the radial stresses (S11 in Figure 9) shows higher tensile forces in an area that coincides with the location of the main cracks, as they appear in Figure 7a, therefore it is reasonable to justify the damage observed.

The degree of safety is quite large, as also the serviceability margins (0.1/3080, compared to acceptable limits of 1/250). It is unlikely therefore that failure can occur due to excessive weight on the structure, whether dead or imposed load (like snow or blocked rainwater). Small cracks under these conditions are possible however at the areas of maximum tensile forces and lack of maintenance means that rainwater may enter through the cracks at the intrados and moisture can build up. Atmospheric actions therefore like freeze/ thaw cycles and temperature variations can cause the cracks to spread, following the joints. The vaulted structure would have slowly weakened along the edges and the crack from the arches would have slowly spread in the hoop direction of the vault, splitting it into two segments that, together with the degradation of the bed joints, would further degrade into a series of rings, as can be seen today.

The structure sits also on the slope so differential movement could have destabilised the containment of the bays in the longitudinal direction, as also the changes in the crack pattern show. Settlement could have also increased the deformation around the windows of the wall in bay 3 (Figure $7 \mathrm{~b}$ ), which could have originated from the detachment of the vault from the wall (S11 in Figure 9).

\section{REPAIRS}

The understanding of the crack pattern and the dynamics of deformation permitted the planning of the strengthening works in the essential areas, as part of the rehabilitation of the building. At the start of the works, the entire brickwork was stripped down completely from the render and this allowed the crack pattern to be better surveyed. Then, all the mortar joints were scraped in order to ensure that all degraded material was removed. All minor cracks were filled and the joints were repointed. The major structural repair was to stitch the main crack in each arch using a plate in the direction that the hinge is expected to open (Figure 10).

The surrounding areas were cleared from overgrowth and the planting bays close to the wall were removed, while all drainage was refurbished. Once the integrity of the structure was restored, thermal insulation and a waterproofing screed was applied on the vaults and the timber doors were restored 


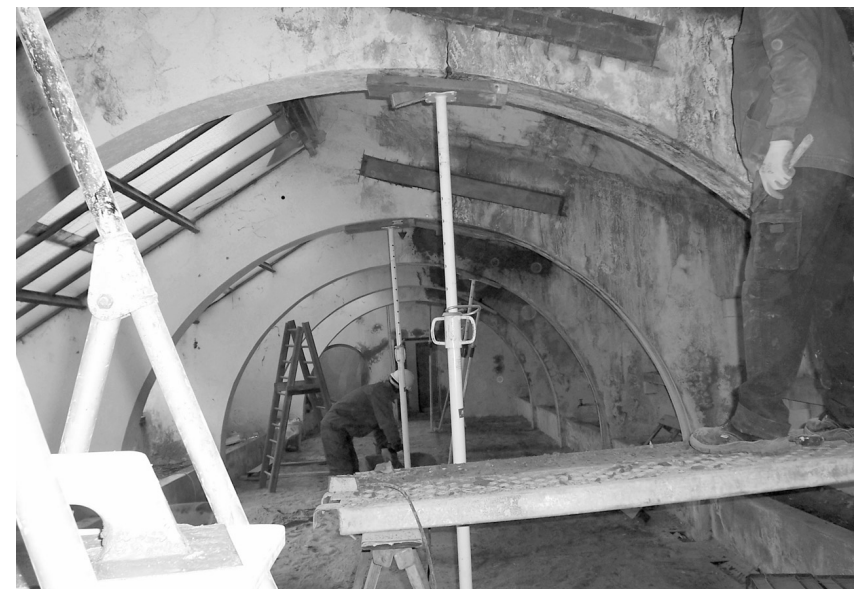

Figure 10. Preliminary stage of repairing and cleaning.

(Figure 11a). In the interior, a new single-coat render was applied. So far as the metal frame of the windows is concerned, all the mullions were cleaned and the glass panels that had not been damaged were placed once again. The damaged ones were replaced with reinforced glass that was distinct from the original panels and for this reason two entire bays were glazed this manner (left bay on Figure 11b). In addition, the most damaged metal mullions were protected from the ingress of water. Eventually, the building at the end of the works is once again the very pleasant multi-functional space that was planned originally (Figure 12).

\section{CONCLUSIONS}

The refurbishment of the Winter Garden at IETcc recovered a relatively unknown minor work of Eduardo Torroja and enriched our knowledge of his structural design ideas and techniques by getting to understand a building made completely from unreinforced masonry.

The structural analysis under dead load has shown high degree of safety of the form and the effect of differential settlement or temperature variation need to be studied in more depth in order to appraise the effect of the site conditions (slope) and the degradation of thermal and water protection of the building.
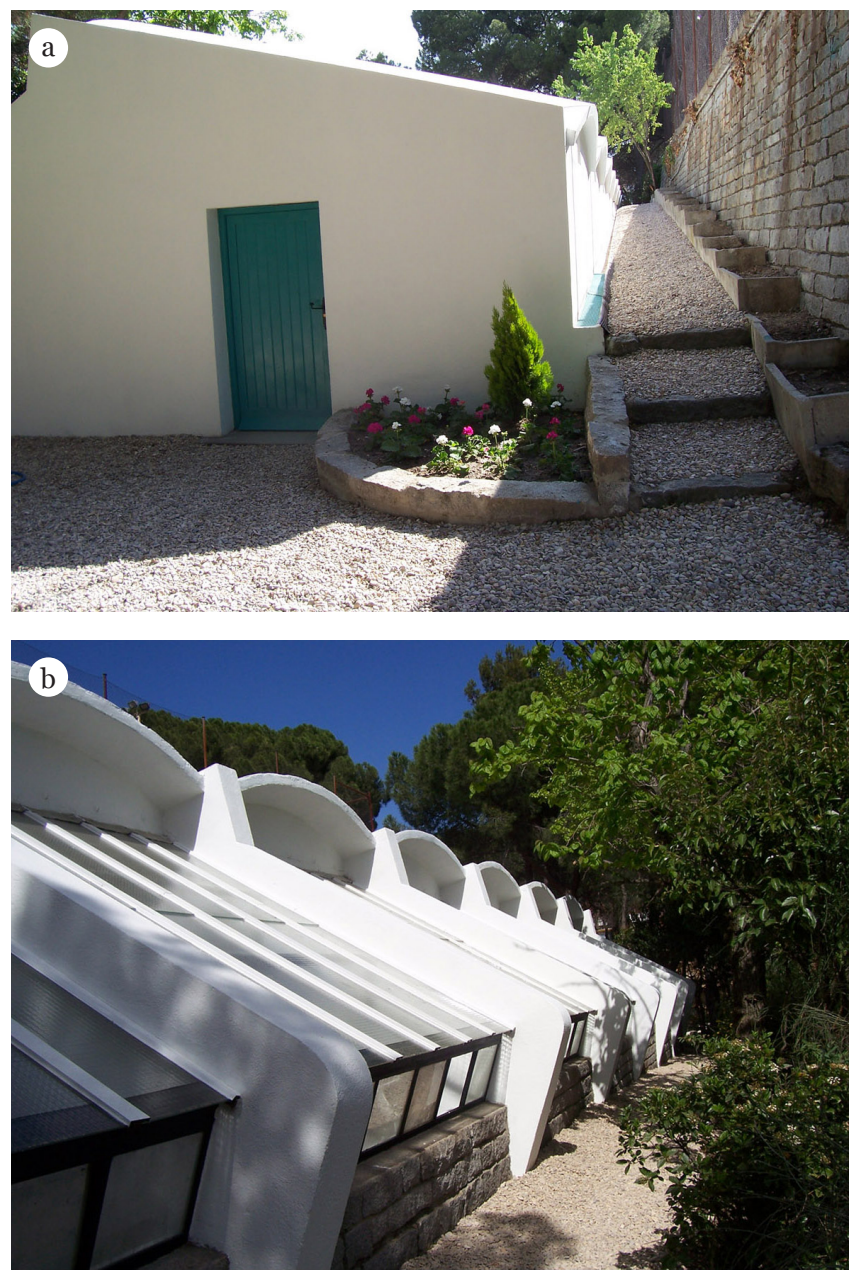

Figure 11. Aspect of north east face (a) and of glazing south elevation (b) after finishing refurbishment works.

The latter have been probably the main cause for the damage observed following neglect in the last years. The analysis has shown the structural origins of the main cracks observed at the arches and the vault, and justified the repairs that restored the integrity of the building focused on the arch. Further research can be carried out in the exact propagation

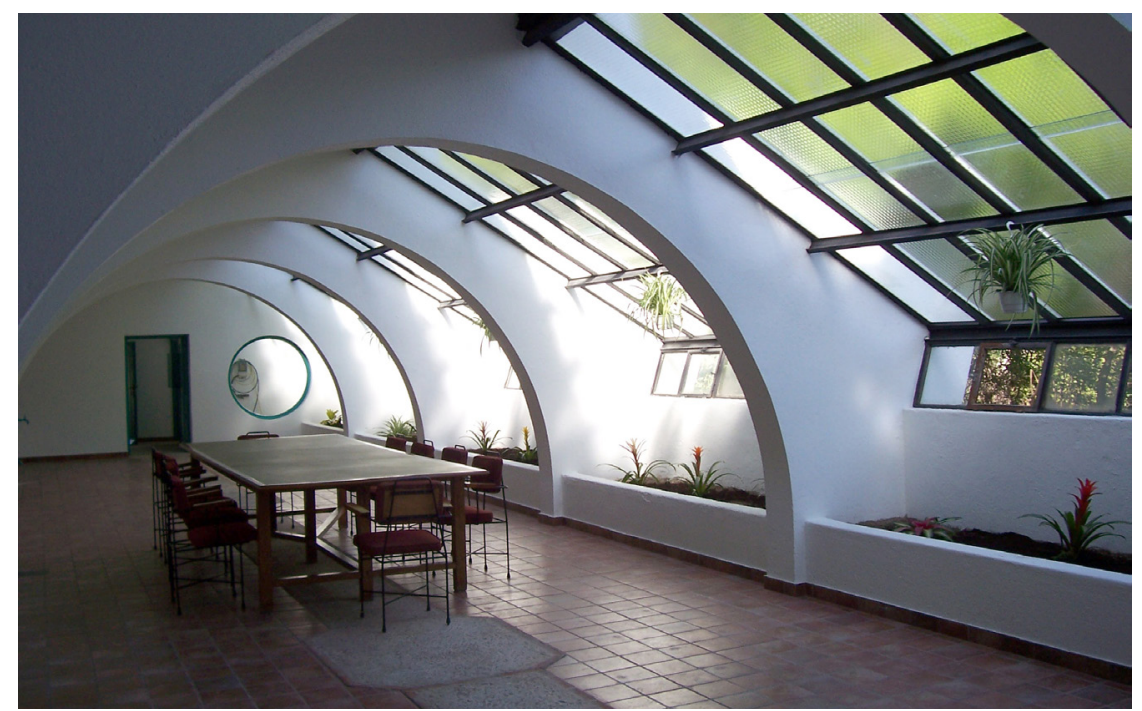

Figure 12. The winter garden after the 2009 refurbishment. 
of the cracks in the vault following degradation of the support conditions along the edges and how it is affected by thermal variation or minor settlement of the ground.

\section{AKNOWLEDGEMENTS}

The authors want to express their special thanks to other members of IETcc especially to Pilar Nasarre, former responsible of the Scientific and Technical Assistance Unit for the various information provided in relation to different surveys performed in the past. They want to express also their gratitude to Julio Mateo from the maintenance unit of IETcc, who was commissioned to perform the Winter Garden refurbishment works, for all the useful information provided in relation to the different repairing works, as this strongly contributes in improving the scope of the paper.

\section{REFERENCES}

(1) Río, O., Sparowitz, L., Tanner, P., Theodossopoulos, D. (2002). Collapse of a RC structure due to an erroneous FEM computer controlled design. En Proc. Sixth Int. Conf. on Computational Structures Technology, (pp. 275-276). CivilComp Press.

(2) Río, O., Theodossopoulos, D., Luxán, MP, Dorrego, F. An Assessment of the collapse of the San Andrés Coastal Tower in Tenerife. En Proc. Tenth Int. Conf. Civil, Structural and Environmental Engineering Computing, (pp. 451-453). CivilComp Press.

(3) Azorín, V., Cassinello, P., Monjo, J. (2012). Archivo Eduardo Torroja. La Sede del itcc (1949-1953). Inéditos anteproyectos previos a su construcción. Informes de la Construcción, 64(525): 5-18 doi: http://dx.doi.org/10.3989/ic.11.023.

(4) IETcc Historic Files: Photographic Records and Plans. IETcc archive.

(5) Oteiza, I., Olaya, M., Fullea, J. (2008) The IETcc Winter Garden. Internal Report presented to the IETcc Board.

(6) Anonymus. (2001). The IETcc Winter Garden (Final Work of the IETcc Master Course CEMCO o1 coordinated by Gutiérrez, J.P.).

(7) Arredondo, F., Benito, C., Echegaray, G., Nadal, J., Paez, A., Del Pozo, F. (1977). La Obra de Eduardo Torroja. Colección Cultura y Ciencia. Madrid: Editado por Instituto de Empresa.

(8) Antuña-Bernardo, J., de las Casas, A. (1999). Eduardo Torroja: Engineer and Constructor. Revista de Obras Públicas, 146: 7-14.

(9) IETcc. (1999). Costillares es así (Especial Centenario Eduardo Torroja), Informes de la Construcción, 51(462), complete volume.

(10) Torroja-Miret, E. (1960). Philosophy of Structures. Berkeley, CA: Univ. Berkeley.

(11) Torroja-Miret, E. (1998). Razón y Ser de los tipos estructurales (9th edition). Madrid: IETcc-CSIC.

(12) Laorden, J. (1954). El Instituto es así. Instalaciones del edificio de Costillares. Informes de la Construcción 6(58): 309-1.

(13) Antuña-Bernardo, J. (2009). Prestressed Constructions without Steel. A Project of the Spanish Engineer Eduardo Torroja. En Proc. Third Int. Congress Constr. History, Cottbus. http://www.bma.arch.unige.it/PDF/CONSTRUCTION_ HISTORY_2009/VOL1/ANTUNA-BERNARDO-joaquin_paper-revised-2-layouted.pdf

(14) Moya-Blanco, L. (1993). Bóvedas tabicadas. Madrid: Colegio Oficial de Arquitectos de Madrid

(15) Sinha, B., Ng, C., Pedreschi, R. (1997). Failure Criterion and Behavior of Brickwork in Biaxial Bending. J. Mat. in Civ. Eng. 9(2): 70-75, doi: http://dx.doi.org/10.1061/(ASCE)o899-1561(1997)9:2(70).

(16) Theodossopoulos, D., Sinha, B., Usmani, A. S. (2003). Case Study of the Failure of a Cross Vault: Church of Holyrood Abbey. J. Archit. Eng, Am. Soc. Civil Eng. (ASCE), 9(3):109-117, doi: http://dx.doi.org/10.1061/(ASCE)10760431(2003)9:3(109).

(17) Theodossopoulos, D., González-Longo, C. (2008). Hybrid masonry shell technology in the work of Idelfonso Sánchez del Río. En Sinha, B., Tanacan, L. (Eds.). Proc. 8th Int. Sem. Structural Masonry. Istanbul. 